\title{
PRODUKSI, KUALITAS, DAN KECERNAAN IN VITRO TANAMAN RUMPUT BENGGALA (Panicum maximum) PADA LAHAN SALIN
}

\section{IN VITRO DIGESTIBILITY, QUALITY, AND YIELD OF GUINEA GRASS (Panicum maximum) ON SALINE SOIL}

\author{
Endang Dwi Purbajanti*¹, R. Djoko Soetrisno ${ }^{2}$, Eko Hanudin ${ }^{3}$, dan Subur Priyono Sasmito Budhi ${ }^{2}$ \\ ${ }^{1}$ Fakultas Peternakan, Universitas Diponegoro, Kampus Baru Tembalang, Semarang \\ ${ }^{2}$ Fakultas Peternakan, Universitas Gadjah Mada, Jl. Fauna No. 3, Bulaksumur, Yogyakarta, 55281 \\ ${ }^{3}$ Fakultas Pertanian, Universitas Gadjah Mada, Jl. Sosio Yustisia, Bulaksumur, Yogyakarta, 55281
}

\section{INTISARI}

Tujuan penelitian untuk mengetahui penampilan rumput benggala yang ditanam di lahan salin dan untuk mengetahui kecernaan bahan kering dan kecernaan bahan organik tanaman pakan secara in vitro. Penelitian penanaman rumput benggala pada lahan pantai yang telah diperbaiki dengan pemberian pupuk kandang 20 ton/ha, gypsum 3 ton/ha dan zwavelzuur ammonium (ZA) dengan populasi tanaman: 10.000, 20.000, dan 30.000 tanaman per hektar. Hasil percobaan menunjukkan populasi yang bertambah meningkatkan $(\mathrm{P}<0,05)$ produksi biomass, produksi bahan kering, produksi protein kasar, neutral detergent fiber (NDF), hemiselulose, dan lignin tetapi menurunkan $(\mathrm{P}<0,05)$ kadar protein kasar dan kecernaan bahan organik secara in vitro. Populasi meningkat tidak meningkatkan acid detergent fiber (ADF) dan kecernaan bahan kering secara in vitro. Jadi daerah pantai yang bersifat salin dapat digunakan untuk penanaman rumput benggala dengan pemberian pupuk kandang 20 ton/ha dan gypsum 3 ton/ha serta $50 \mathrm{~kg} \mathrm{~N} / \mathrm{ha}(239$ $\mathrm{kg}$ pupuk ZA/ha) sebagai sumber nitrogen.

(Kata kunci: Rumput pakan, Tanah salin, Pupuk kandang, Gypsum, Sumber nitrogen)

\section{ABSTRACT}

The aim of this study was to evaluate performance and in vitro digestibility of Guinea grass grown on saline soil. Yield, quality, and in vitro digestibility of Guinea grass cultivated on coastal area with crop populations of 10,000, 20,000, and 30,000 plants per hectare. Experiment was conducted following randomized complete block design (RCBD). Higher crop population increased fresh and DM biomass production, crude protein (CP) yield, dry matter (DM) content, neutral detergent fiber (NDF), lignin, and hemicellulose content, but decreased CP content, and in vitro organic matter digestibility (OMD). The increased population had no effect on acid detergent fiber (ADF) and in vitro dry matter digestibility (DMD). It could be concluded that guinea grass was recommended to be planted in saline coastal area by addition of fertilizer 20 tons/ha manure, 3 tons/ha gypsum, and $50 \mathrm{~kg} \mathrm{~N}(239 \mathrm{~kg} \mathrm{ZA/ha})$ as source of nitrogen.

(Keywords: Forage, Salinity, Saline soil, Manure, Gypsum, Nitrogen source)

\section{Pendahuluan}

Pertumbuhan tanaman pada kondisi salin akan terhambat akibat tingginya konsentrasi garam atau ion natrium $(\mathrm{Na})$. Bila kadar garam yang tinggi berhubungan langsung dengan sel tanaman maka akan terjadi pengerutan protoplasma. Toleransi tanaman pada konsentrasi $\mathrm{NaCl}$ akan merujuk 3 kriteria yaitu: (1) kemampuan tanaman survive pada tanah salin, (2) kemampuan tanaman mengeluarkan hasil pada konsentrasi $\mathrm{NaCl}$ dan (3) hasil relatif tanaman pada tanah salin dibandingkan dengan

\footnotetext{
* Korespondensi (corresponding author):

Telp. +6282138222324

E-mail: edpurbajanti@yahoo.com
}

kondisi non salin (Jian-Kang, 2001). Menurut Ashraf dan Orooj (2006) pada tanaman Trachyspermum ammi (L) Sprague konsentrasi garam yang meningkat sampai $120 \mathrm{mM}$ menurunkan biomas tajuk dan akar serta hasil biji, penurunan pada tajuk sebesar $27 \%$ dan pada biji hampir 50\%. Salinitas menurunkan laju pertumbuhan daun melalui pengurangan laju pembesaran sel pada daun. Penelitian Qian et al. (2001) dan Amezketa et al. (2005) menyatakan bahwa salinitas menyebabkan terhambatnya pertumbuhan tanaman dan perubahan struktur tanaman, antara lain lebih kecilnya ukuran daun, lebih rapatnya stomata, dan lignifikasi akar yang lebih awal. 
Lignin menghambat kecernaan hemiselulose dan selulose (Jung dan Vogel, 1986). Beberapa faktor penyebab kecernaan NDF adalah jumlah lignin, hibrid atau varitas, kesuburan tanah, kondisi lingkungan, dan pemanenan hijauan serta penyimpanan (Downing dan French, 2009). Kandungan serat kasar yang rendah menyebabkan tingginya kecernaan bahan kering (Cherney et al., 1992). Populasi tanaman jagung yang meningkat mengakibatkan peningkatan hasil biji jagung 4,2\% (Stranger dan Lauer, 2006), bahan kering, NDF, dan ADF tetapi menurunkan kecernaan bahan kering dan kadar protein kasar (Widdicombe dan Thelen, 2002). Populasi tanaman kedelai yang meningkat meningkatkan indeks luas daun dan hasil biji kedelai (Holshouser dan Whittaker, 2002). Neutral detergent fiber merupakan komponen dinding sel termasuk selulose, hemiselulose, lignin, dan heat damage protein. Neutral detergent fiber berhubungan dengan bulkiness dan forage intake (Berdahl et al., 2004). Kadar protein kasar dipengaruhi oleh jenis tanaman, umur panen, dan tinggi pemotongan. Tanaman yang berdaun banyak mempunyai kadar protein tinggi, umur panen yang terlambat akan menurunkan kadar protein kasar sedangkan tinggi pemotongan $30 \mathrm{~cm}$ mempunyai kadar protein kasar yang lebih tinggi dibanding 15 $\mathrm{cm}$. Hasil bahan kering yang meningkat mengakibatkan kadar protein kasar turun (Bilbao et al., 2004).

Hasil penelitian Orndorff et al. (2008) menunjukkan bahwa kandungan $\mathrm{Na}$ tertukar sebesar 1,62 mili ekuivalen/100g pada tanah salin menyebabkan air sulit diserap oleh tanaman, akibatnya tekanan turgor menjadi rendah. Tekanan turgor berhubungan dengan membuka dan menutupnya stomata. Rapatnya stomata menjadikan karbondioksida yang masuk sedikit. Karbondioksida merupakan salah satu bahan dasar yang amat penting dalam proses fotosintesis untuk menghasilkan karbohidrat sebagai komponen bahan kering tanaman. Hasil penelitian Scarbrough et al. (2004) menunjukkan bahwa rumput orchard mempunyai kandungan NDF, ADF, selulose, hemiselulose, dan lignin masing-masing 64-71, 32-37, 28-32, 31-36 dan 39-47\%, sedangkan bermuda grass berturut-turut adalah 74-77, 31-33, 27-28, 4244 dan 42-44\%. Lauer dan Rankin (2004) menemukan bahwa NDF dan ADF hijauan menurun bila kecernaan in vitro meningkat.

Tujuan penelitian untuk mengetahui penampilan rumput benggala yang ditanam di lahan salin dan untuk mengetahui kecernaan bahan kering dan kecernaan bahan organik tanaman pakan secara in vitro.

\section{Materi dan Metode}

Penelitian merupakan percobaan lapangan pada lahan salin di pantai Utara Jawa yaitu pada Desa Bulak Baru, Jepara dari 1 April sampai 30 September 2008. Penelitian menggunakan rumput benggala (Panicum maximum), lahan salin pantura Jepara, gypsum, pupuk kandang, pupuk $\mathrm{KNO}_{3}$, dan pupuk ZA.

Percobaan menggunakan metode percobaan lapang, dilakukan dengan menggunakan Rancangan Acak Kelompok (randomized complete block design) yang diulang 5 kali (Steel dan Torrie, 1990). Perlakuan yang diterapkan adalah populasi tanaman (1) populasi 10.000 tanaman per hektar (jarak tanam 1x1 m), (2) populasi 20.000 tanaman per hektar (jarak tanam 1x0,5 m), dan (3) populasi 30.000 tanaman per hektar (jarak tanam 1x0,33 m). Ukuran petak $5 \times 4 \mathrm{~m}^{2}$, jarak tanam $1 \times 1 \mathrm{~m}$ berarti 20 tanaman/petak, jarak tanam $1 \times 0,5 \mathrm{~m}$ berarti 40 tanaman/petak dan jarak tanam $1 \times 0,33 \mathrm{~m}$ berarti 60 tanaman/petak.

Tanah pantai dipersiapkan dengan cara mengolah dan membuat petak. Arah guludan searah dengan arah pantai. Petak kemudian diberi gypsum sebanyak 3 ton/ha (6 kg/petak) dan pupuk kandang 20 ton/ha (40 kg/petak) dengan cara ditabur dan dibenamkan kedalam tanah kemudian dibiarkan selama empat minggu. Bibit tanaman terpilih dipersiapkan dari bahan tanam stek yang disemaikan pada media campuran tanah dan pupuk kandang dengan perbandingan 1:1. Tanaman diberi pupuk ZA sebanyak $50 \mathrm{~kg} \mathrm{~N} / \mathrm{ha}(0,47 \mathrm{~kg} /$ petak $), \mathrm{SP} 36100$ $\mathrm{kg}_{2} \mathrm{O}_{5} / \mathrm{ha}\left(0,5 \mathrm{~kg} /\right.$ petak) dan $\mathrm{KCl} 100 \mathrm{~kg} \mathrm{~K}{ }_{2} \mathrm{O} / \mathrm{ha}$ $(0,3 \mathrm{~kg} /$ petak $)$ yang diberikan pada saat penanaman. Pemberian pupuk nitrogen sumber amonium (amonium sulfat $=$ ZA) dengan cara dibenamkan kedalam tanah pada jarak $7 \mathrm{~cm}$ dari pangkal tanaman sedalam $5 \mathrm{~cm}$. Tanaman juga mendapatkan pupuk hara mikro dengan dosis $1 \mathrm{~g} /$ liter yang disemprotkan seminggu sekali. Pada umur satu bulan tanaman diseragamkan dengan cara potong paksa, dan enam minggu kemudian dilakukan panen.

Variabel yang diamati meliputi produksi berat segar, kadar bahan kering, produksi bahan kering, kadar protein (Kjedahl), produksi protein kasar, NDF ADF, lignin, dan hemiseloluse berdasar metode Van Soest (1994), kecernaan bahan kering $(\mathrm{KcBK})$, kecernaan bahan organik $(\mathrm{KcBO})$ in vitro dengan metode Tilley dan Terry.

Data dari hasil pengamatan kemudian ditabulasi dan disidik ragam kemudian diuji lanjut berdasarkan DMRT (Duncan's new Multiple Range Test) berdasarkan petunjuk Steel dan Torrie (1990) menggunakan program SAS. 


\section{Hasil dan Pembahasan}

\section{Hasil biomas}

Populasi tanaman berpengaruh terhadap hasil karbohidrat disebabkan pada proses fotosintesis populasi yang rapat berarti jumlah tanaman yang berfotosintesis semakin banyak. Hal ini akan menghasilkan jumlah karbohidrat yang lebih banyak. Sebagai akibatnya konsentrasi bahan kering (BK) tanaman juga lebih banyak. Hasil karbohidrat berbanding lurus dengan konsentrasi BK, jika konsentrasi BK meningkat maka hasil hijauan dan hasil bahan kering juga meningkat. Peningkatan hasil berbanding lurus dengan pertumbuhan relatif dan hasil bersih fotosintesis.

Hasil biomas meningkat dengan meningkatnya populasi. Respon hasil biomas akibat populasi berbentuk linier $(y=0,0002 x+3,07333)$ dengan $\mathrm{R}^{2}=0,8268$, berarti bahwa faktor populasi mempengaruhi hasil biomas sebesar $82,68 \%$. Peningkatan populasi 20.000-30.000 meningkatkan hasil bahan kering dan protein kasar. Respon hasil bahan kering akibat populasi berbentuk linier $(\mathrm{y}=$ $0,0005 x+4,4)$ dengan $R^{2}=0,8141$, berarti bahwa semakin bertambah populasi maka hasil bahan kering semakin meningkat. Respon hasil protein kasar akibat populasi berbentuk linier $(y=0,0002 x$ $+1,02)$ dengan $\mathrm{R}^{2}=0,9993$, berarti bahwa semakin bertambah populasi hasil protein kasar semakin meningkat. Hal ini diduga pada tingkat populasi yang dicobakan belum terjadi persaingan terhadap cahaya, air, dan hara sehingga populasi masih dapat ditingkatkan.

Karbondioksida merupakan bahan dasar dalam proses fotosintesis untuk menghasilkan karbohidrat. Hasil fotosintesis yang tinggi akan berakibat pada meningkatnya hasil biomas. Selain itu, dalam percobaan pupuk nitrogen yang diberikan berasal dari ZA $50 \mathrm{~kg} \mathrm{~N} / \mathrm{ha}$ dan pupuk kandang (konsentrasi N 1,67\%) yang setara dengan $333 \mathrm{~kg}$ $\mathrm{N} / \mathrm{ha}$ ) dapat digunakan tanaman untuk proses pertumbuhan dan fisiologis diantaranya pembentukan daun, perpanjangan batang, pembentukan anakan, dan penumpukan bahan kering serta protein kasar. Peningkatan populasi sampai 30.000 tanaman/ hektar masih efisien karena bentuk persamaannya linier dan mampu menghasilkan biomas yang bertambah.

Hasil percobaan menunjukkan bahwa bila populasi tanaman ditingkatkan 3 kali (dari 10.000 menjadi 30.000) maka hasil hijauan meningkat $76,33 \%$, sedangkan hasil penelitian Widdicombe dan Thelen (2002) pada tanaman jagung dilaporkan bahwa konsentrasi bahan kering hijauan jagung dan hasil hijauan meningkat apabila jarak baris dari 76 dirapatkan menjadi $38 \mathrm{~cm}$, yang berarti bahwa populasi ditingkatkan dua kali lipat, masing-masing meningkat $13,5 \%$ dan 5,4\%. Hasil hijauan hasil penelitian lebih tinggi bila dibandingkan penelitian Utomo et al. (1983) yang menggunakan pot berdiameter $50 \mathrm{~cm}$ (populasi setara 40.000 per ha) maka hasil rumput benggala tanpa naungan adalah sebesar 37,92 gram/pot atau setara 1,52 ton/ha.

\section{Bahan kering dan protein kasar hijauan}

Populasi yang semakin bertambah meningkatkan kadar bahan kering tanaman dan menurunkan kadar protein kasar. Pada penelitian yang dilakukan pemupukan dengan pupuk kandang dan ZA dihitung berdasarkan luas area (petak), sehingga masing-masing petak mempunyai dosis pupuk kandang maupun ZA yang sama yaitu $40 \mathrm{~kg}$ pupuk kandang dan $1 \mathrm{~kg}$ ZA. Hal ini berpengaruh pada jumlah nitrogen yang didapatkan masing-masing tanaman setiap populasi, yang berarti bahwa populasi 10.000 mendapatkan jumlah nitrogen paling banyak dan populasi 30.000 mendapatkan jumlah nitrogen paling sedikit.

Dari hasil percobaan diketahui bahwa pada populasi tinggi terjadi persaingan cahaya sehingga tanaman tumbuh lebih tegak dengan struktur batang yang lebih kecil dan jumlah daun yang lebih sedikit. Sebagai akibatnya jumlah bahan kering ditumpuk pada batang sehingga kadar bahan kering pada populasi lebih tinggi adalah lebih besar.

Kandungan dan komposisi protein kasar dalam hijauan dipengaruhi oleh ketersediaan nitrogen dalam larutan tanah. Pada populasi 10.000 mendapatkan jumlah nitrogen per tanaman paling tinggi, diikuti populasi 20.000 dan 30.000 .

Tabel 1. Hasil biomas, bahan kering, dan protein kasar rumput benggala di tanah salin (the production of biomass, dry matter and crude protein of benggala grass at saline soil)

\begin{tabular}{|c|c|c|c|}
\hline $\begin{array}{l}\text { Populasi (batang/ha) } \\
\text { (population (stem/ha)) }\end{array}$ & $\begin{array}{l}\text { Hasil biomas (ton/ha) } \\
\text { (biomass yield } \\
(\text { ton } / \text { ha }))\end{array}$ & $\begin{array}{l}\text { Hasil bahan kering }(100 \mathrm{~kg} / \mathrm{ha}) \\
(\text { dry matter yield }(100 \mathrm{~kg} / \mathrm{ha}))\end{array}$ & $\begin{array}{l}\text { Hasil protein } \mathrm{kasar}(100 \mathrm{~kg} / \mathrm{ha}) \\
\text { (crude protein yield }(100 \mathrm{~kg} / \mathrm{ha}))\end{array}$ \\
\hline 10.000 & $4,90 \pm 0,96^{\mathrm{c}}$ & $7,68 \pm 6,72^{b}$ & $2,73 \pm 0,54^{c}$ \\
\hline 20.000 & $6,90 \pm 0,55^{\mathrm{b}}$ & $15,96 \pm 2,52^{\mathrm{a}}$ & $4,34 \pm 0,22^{\mathrm{b}}$ \\
\hline 30.000 & $8,64+0,38^{\mathrm{a}}$ & $16,74 \pm 2,27^{\mathrm{a}}$ & $6,10 \pm 0,63^{\mathrm{a}}$ \\
\hline
\end{tabular}

$\overline{\mathrm{a}, \mathrm{b}, \mathrm{c}}$ Superskrip yang berbeda pada kolom yang sama menunjukkan perbedaan yang nyata $(\mathrm{P}<0,05)$ (different superscripts at the same column indicate significant differences $(P<0.05))$. 

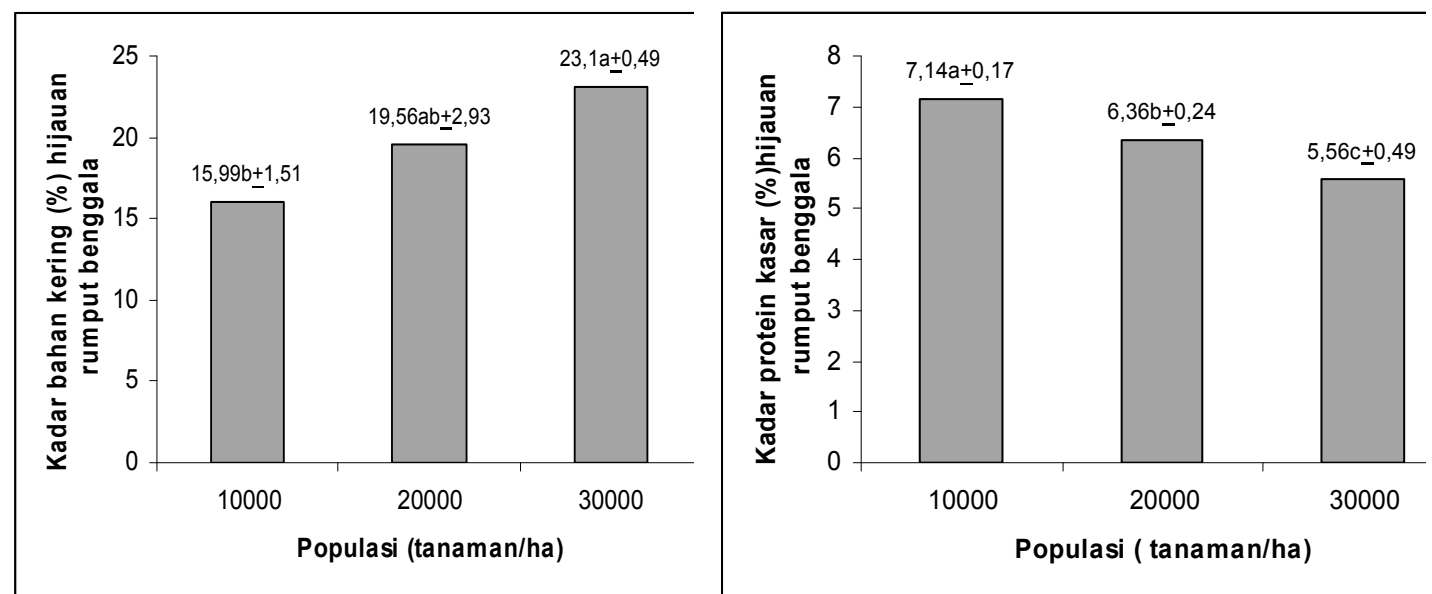

Gambar 1. Kadar bahan kering dan protein kasar hijauan rumput benggala pada tanah salin (dry matter and crude protein contents of benggala grass at saline soil)

Tingginya kandungan protein kasar pada populasi 10.000 (jumlah tanaman 20 tanaman/petak) dikarenakan setiap tanaman memperoleh nitrogen yang lebih banyak dibanding pada populasi 20.000 (40 tanaman/petak) dan 30.000 (60 tanaman/petak) karena dosis nitrogen ditentukan per satuan luas. Oleh karena itu kadar protein kasar paling tinggi adalah populasi $10.000(7,14 \%)$ yang berbeda nyata dengan populasi $20.000(6,30 \%)$ dan populasi $30.000(5,56 \%)$. Hasil penelitian sama dengan hasil penelitian Widdicombe dan Thelen (2002) pada tanaman jagung dilaporkan bahwa populasi yang meningkat dari 64.200 menjadi 88.900 tanaman/ha menurunkan kandungan protein kasar hijauan jagung.

Protein merupakan senyawa organik kompleks yang mengandung 22 asam amino dengan berbagai proporsi yang berbeda. Bersama dengan karbohidrat dan lemak, asam amino mengandung karbon, hidrogen dan oksigen, tetapi semua asam amino mengandung nitrogen. Kadar protein hijauan dipengaruhi oleh jenis tanaman (spesies, kultivar), lintang, bagian tanaman, stadium pertumbuhan, kesuburan tanah, iklim (musim), temperatur, intensitas cahaya dan stres air.

Protein kasar rumput benggala hasil penelitian yaitu 5,56 sampai 7,14\% lebih rendah dari penelitian Hartadi et al. (1997) bahwa berdasarkan $100 \%$ bahan kering rumput benggala memiliki kadar protein kasar sebesar 7,70\%. Protein kasar hasil penelitian lebih rendah bila dibandingkan penelitian Utomo et al. (1983) yang menggunakan pot berdiameter $50 \mathrm{~cm}$ (setara populasi 40.000 per ha) rumput benggala mempunyai kadar protein kasar (tanpa naungan) adalah sebesar 8,85\%. Protein kasar rumput benggala yang dipanen umur 6 minggu (Chen dan Hutton, 1992) adalah 9,11\%. Kadar protein kasar hijauan dipengaruhi oleh perbandingan daun/batang, fase pertumbuhan pada waktu potong dan kesuburan tanah. Kadar protein hijauan ditentukan ketersediaan amonium bagi tanaman, faktor genetik dan lingkungan tempat hidupnya. Hasil penelitian Aganga dan Tshwenyane (2004), pada rumput benggala yang dipanen pada 6 minggu, kandungan bahan kering, protein kasar, NDF, ADF, dan kecernaan bahan organik secara in vitro masing-masing $25,9,6,57,8-65,8,25-35,3$ dan $56,9-87,73 \%$.

\section{Komponen serat}

Dinding sel dan isi sel merupakan komponen yang berasal dari hijauan yang berhubungan dengan kemampuan cerna. Semakin tinggi populasi tanaman maka terjadi penurunan nilai NDF yang berarti bahwa kandungan isi sel menjadi semakin bertambah.

Populasi 20.000-30.000 meningkatkan NDF hijauan diduga saat percobaan dosis pupuk $\mathrm{N}$ (ZA) dan pupuk kandang yang diberikan dihitung dalam satuan per hektar, sehingga dengan ukuran petak yang sama, maka tanaman pada populasi 20.000 dan 30.000 mendpatkan jumlah $\mathrm{N}$ yang lebih sedikit. Hal ini berakibat tanaman pada populasi 10.000 mempunyai sumber $\mathrm{N}$ yang cukup untuk membentuk isi sel sehingga NDF nya rendah.

Fenomena kandungan NDF dan NDS hasil penelitian diduga berhubungan dengan kadar bahan kering dan protein kasar hijauan. Pola peningkatan NDF sama dengan pola bahan kering sedangkan NDS sama dengan protein kasar hijauan. Bahan kering merupakan cerminan penumpukan karbohidrat.

Widdicombe dan Thelen (2002) melaporkan bahwa persentase NDF hijauan tanaman jagung meningkat secara linier bila populasi meningkat dari 64.200 menjadi 88.900 tanaman/ha. Kandungan serat detergent netral (NDF) digunakan untuk estimasi dari kemampuan ternak untuk meng- 
konsumsi hijauan. Downing dan French (2009) melaporkan bahwa NDF sangat diperlukan oleh ruminansia karena berhubungan dengan intake bahan kering dan hasil lemak. Meningkatnya kecernaan NDF sebesar 1\% menaikkan intake bahan kering sebesar 0,37 pon dan hasil lemak 0,55 pon.

Peneliti Huntington dan Burns (2008) melaporkan bahwa dibandingkan dengan rumput perennial rye grass dan meadow fescue maka NDF rumput benggala hasil penelitian adalah tinggi yaitu 63,56 sampai $80,74 \%$ sedangkan perennial rye grass dan meadow fescue mempunyai NDF rerata 392-452 dan 418-469 $\mathrm{g} / \mathrm{kg}$ atau 39,2 sampai 46,9\% (Brink et al., 2007). Nilai nutrisi tanaman sulla (Hedysarum coronarium L) dipengaruhi oleh umur tanaman yang berpengaruh pada rasio daun batang tanaman, NDF antara 200-616 g/kg DM dan kadar protein kasar 107-295 bg/kg DM (Borreani et al., 2003). Beberapa faktor penyebab kecernaan NDF adalah jumlah lignin, hibrid atau varitas, kesuburan tanah, kondisi lingkungan, dan pemanenan hijauan serta penyimpanan (Downing dan French, 2009). Menurut Huntington dan Burns (2008) kandungan NDF hay switch grass yang dipanen pada sore hari lebih besar dibanding pemanenan pada pagi hari, hal ini disebabkan karena penyinaran matahari mempengaruhi penyusunan dinding sel. Brink et al. (2007) melaporkan bahwa kandungan NDF perennial rye grass dan meadow fescue rerata 392452 dan 418-469 g/kg atau 39,2 sampai 46,9\%.

Kadar ADF rumput pada semua populasi menunjukkan nilai yang tidak berbeda (Tabel 2). Pada percobaan yang dilakukan, populasi padat mendapatkan jumlah $\mathrm{N}$ dan pupuk kandang yang sama dengan populasi jarang. Kadar ADF yang tidak berbeda nyata kemungkinan karena belum terjadi persaingan dalam memperoleh cahaya, hara dan air yang berakibat pada pembentukan serat tanaman. Kadar ADF yang tidak berbeda nyata karena peningkatan populasi senada dengan penelitian Graybill et al. (1991) bahwa meningkatnya kerapatan tanaman jagung tidak berpengaruh terhadap kualitas hijauan termasuk ADF dan NDF. Sebaliknya, peneliti Widdicombe dan Thelen (2002) melaporkan bahwa persentase ADF hijauan tanaman jagung meningkat secara linier bila populasi meningkat dari 64.200 menjadi 88.900 tanaman/ha.

Serat tanaman mempunyai tiga komponen utama yaitu selulose, hemiselulose, dan lignin. Selulose dan hemiselulose bisa dicerna oleh kebanyakan ruminansia. Ruminansia mampu mengubah komponen serat menjadi energi karena rumen merupakan lingkungan yang baik bagi bakteria dan mikroorganisme untuk memecah serat. Lignin tidak dapat dicerna, oleh karena itu tidak digunakan oleh ruminansia sebagai energi. Energi seekor ternak diterima dari pakan yang berasal dari karbohidrat

Tabel 2. Kadar ADF, lignin dan hemiselulose hijauan rumput benggala $(A D F$, lignin and hemicellulose contents of benggala grass)

\begin{tabular}{cccc}
\hline $\begin{array}{c}\text { Populasi (batang/ha) } \\
\text { (population (stem/ha) }\end{array}$ & ADF (\%) & Lignin (\%) & $\begin{array}{c}\text { Hemiselulose (\%) } \\
\text { (hemicellulose (\%)) }\end{array}$ \\
\hline 10.000 & $43,93 \pm 0,79$ & $4,28 \pm 0,14^{\mathrm{b}}$ & $20,21 \pm 7,38^{\mathrm{b}}$ \\
20.000 & $45,63 \pm 2,85$ & $5,90 \pm 0,60^{\mathrm{a}}$ & $30,10 \pm 6,73^{\mathrm{ab}}$ \\
30.000 & $43,36 \pm 3,76$ & $6,82 \pm 0,74^{\mathrm{a}}$ & $36,81 \pm 7,42^{\mathrm{a}}$ \\
\hline
\end{tabular}

${ }^{\mathrm{a}, \mathrm{b}}$ Superskrip yang berbeda pada kolom yang sama menunjukkan perbedaan yang nyata $(\mathrm{P}<0,05)$ (different superscripts at the same column indicate significant differences $(P<0.05))$.

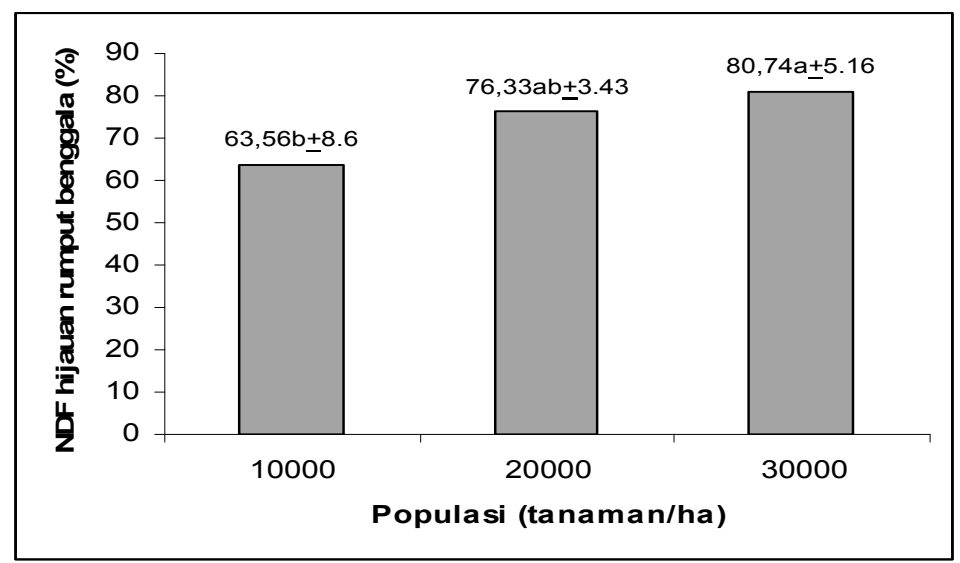

Gambar 2. Nilai NDF hijauan rumput benggala akibat populasi tanaman yang berbeda (NDF value of benggala grass at different population size) 
yang dikombinasi dengan karbohidrat tidak berserat (biji) dan karbohidrat serat. Bila fraksi serat tercerna meningkat total energi bruto hijauan juga meningkat sebagai total feed intake. Lignin menghambat kecernaan hemiselulose dan selulose (Jung dan Vogel, 1986). Semakin tinggi populasi maka kandungan hemiselulose semakin meningkat. Nilai hemiselulose tidak terlepas dari nilai NDF dan ADF. Hal ini dikarenakan kandungan NDF bertambah sedangkan ADF tidak berbeda nyata dengan populasi yang meningkat. Peningkatan hemiselulose diduga akibat lebih sedikitnya unsur hara $\mathrm{N}$ pada populasi rapat yang diperoleh oleh masing-masing tanaman, hal ini menyebabkan kandungan isi sel berkurang, yang berarti dinding sel bertambah. Hemiselulose termasuk serat yang bisa dicerna oleh ruminansia sehingga keberadaannya bersifat menguntungkan dari segi nilai pakan. Pemanenan hijauan berpengaruh pada ADF, acid detergent lignin (ADL), $\mathrm{P}$, dan $\mathrm{N}$ hijauan, pemanenan pada bulan Maret (awal musim semi) mempunyai ADF, ADL, N, dan $\mathrm{P}$ yang lebih rendah dibanding pemanenan bulan April dan Mei pada tanah black medic Texas (Muir et al., 2003).

\section{Kecernaan hijauan rumput benggala}

Populasi mengakibatkan efek yang sama pada KcBK namun mengakibatkan efek yang berbeda pada kecernaan bahan organik hijauan (Tabel 3). Kecernaan bahan kering terdiri dari bahan organik dan bahan anorganik pada pakan yang dapat dicerna oleh tubuh, bahan anorganik terdiri dari mineral sedangkan bahan organik terdiri atas senyawa bernitrogen, karbohidrat, lemak, dan vitamin.

Kecernaan bahan kering dipengaruhi oleh konsentrasi lignin. Acid detergent fiber dapat digunakan untuk menduga dinding sel atau KcBK untuk semua pakan (Reeves, 1985). Sesuai dengan Reeves (1985) hasil penelitian ADF hijauan rumput benggala mengakibatkan efek yang sama, yang berarti bahwa jumlah dinding sel yang terbentuk pada populasi 10.000 hingga 30.000 mempunyai kekerasan yang sama sehingga menghasilkan KcBK yang tidak berbeda nyata. Kefale dan Ranamukhaarachchi (2006) menyatakan bahwa kecernaan pakan memberikan respon yang dihambat lignin merupakan kurve linier karena mekanisme penghambatan oleh lignin adalah kompleks.

Populasi 30.000 menurunkan KcBO hijauan, diduga berhubungan dengan kandungan protein kasar hijauan dimana semakin tinggi populasi kandungan protein kasar hijauan semakin rendah juga mempunyai kandungan isi yang tinggi. Unsur nitrogen dalam hijauan berpengaruh pada jumlah bahan organik yang disusun dalam hijauan sehingga akan meningkatkan KcBO. Kecernaan bahan organik berhubungan dengan kandungan komposisi kimia hijauan yaitu N, abu, ekstrak eter, dinding sel, ADF, ADL, dan silika dimana bertambahnya persentase dinding sel, ADL, silika, dan ekstrak eter akan menurunkan KcBO hijauan (Muir et al., 2003).

Kecernaan bahan organik meningkat karena pada waktu fermentasi in vitro fraksi serat yang terdiri dari selulose dan hemiselulose telah mengalami penguraian menjadi senyawa yang lebih sederhana. Penguraian tersebut membantu mikrobia cairan rumen dalam tabung fermentasi in vitro untuk mensekresikan enzim dan mampu mencerna bahan organik hijauan dengan lebih baik. Dalam proses respirasi aerobik, enzim tanaman akan menggunakan gula tanaman termasuk karbohidrat mudah larut untuk menghasilkan energi. Adanya serat pada saat fermentasi in vitro merupakan faktor yang esensiil untuk mempercepat pertumbuhan dan proliferasi mikrobia rumen. Ketersediaan energi tinggi yang berasal dari bahan pakan pada saat fermentasi in vitro menyebabkan kemampuan mikrobia rumen untuk mendegradasi komponen organik bahan pakan semakin meningkat. Peningkatan kemampuan degradasi tersebut akan berakibat terhadap peningkatan kecernaan terhadap bahan pakan. Enzim mikrobial akan menggunakan isi sel tanaman sebagai media tumbuhnya.

Kecernaan bahan organik berhubungan dengan kandungan komposisi hijauan yaitu nitrogen, abu, ekstrak eter, komponen dinding sel, ADF, ADL, dan silika. Kecernaan bahan organik dapat diprediksi dengan persamaan regresi berganda komponen dinding sel, ADL, silika, dan ekstrak

Tabel 3. Rerata kecernaan bahan kering dan bahan organik in vitro rumput benggala yang ditanam di lahan salin (dry matter and organic matter in vitro digestibility of benggala grass at saline soil)

\begin{tabular}{ccc}
\hline \hline $\begin{array}{c}\text { Populasi (batang/ha) } \\
\text { (population (stem/ha) })\end{array}$ & $\begin{array}{c}\text { Kecernaan bahan kering (\%) } \\
(\text { dry matter digestibility (\%)) }\end{array}$ & $\begin{array}{c}\text { Kecernaan bahan organik (\%) } \\
\text { (organic matter digestibility (\%)) }^{\text {organ }}\end{array}$ \\
\hline 10.000 & $43,99 \pm 4,52^{\mathrm{a}}$ & $51,02 \pm 2,23^{\mathrm{a}}$ \\
20.000 & $43,07 \pm 2,18^{\mathrm{a}}$ & $42,75 \pm 4,95^{\mathrm{b}}$ \\
30.000 & $41,48 \pm 1,77^{\mathrm{a}}$ & $42,40 \pm 6,62^{\mathrm{b}}$
\end{tabular}

${ }^{\bar{a}, \mathrm{~b}}$ Superskrip yang berbeda pada kolom yang sama menunjukkan perbedaan yang nyata $(\mathrm{P}<0,05)$ (different superscripts at the same column indicate significant differences $(P<0.05))$. 
eter. Setiap penambahan kandungan silika 1\% dalam hijauan menurunkan KcBO 1\% (Huntington dan Burns, 2008).

Kecernaan bahan kering dan $\mathrm{KcBO}$ secara in vitro hasil penelitian adalah 41,48-43,99\% (KcBK) dan 42,50-51,52\% (KcBO). Menurut Chen dan Hutton (1992) KcBK secara in vitro rumput benggala yang dipanen umur 6 minggu adalah $53,88 \%$.

\section{Kesimpulan}

Pertambahan populasi meningkatkan hasil biomas, bahan kering, protein kasar, NDF, hemiselulose, dan lignin tetapi menurunkan kadar protein kasar dan $\mathrm{KcBO}$ in vitro. Populasi yang bertambah tidak mempengaruhi nilai $\mathrm{ADF}$ dan KcBK secara in vitro.

\section{Ucapan Terima Kasih}

Terima kasih kepada Direktorat Pendidikan Tinggi Kementerian Pendidikan Nasional atas beasiswa BPPS yang penulis terima dari tahun 2005-2008. Terima kasih juga atas bantuan penyelesaian Program Doktor dari Universitas Diponegoro.

\section{Daftar Pustaka}

Aganga, A.A. and S. Tshwenyane. 2004. Potentials of guinea grass (Panicum maximum) as forage crops in livestock production. Pakistan Journal of Nutrition 3(1): 1-4.

Amezketa, E., R. Aragues, and R. Gazol. 2005. Efficiency of sulfuric acid, mined gypsum and gypsum by product in soil crosing prevention and sodic soil reclamation. Agron. J. 97: 983-989.

Ashraf, M. and A. Orooj. 2006. Salt stress effect on growth, ion accumulation and seed oil concentration in an arid zone traditional medicinal plant ajwain (Trachyspermum ammi L. Sprague). Science Direct, June 2006: 209-220.

Berdahl, J.D., J.F. Karn, and J.R. Hendrickson, 2004. Nutritive quality of cool season grass monoculture and binary grass, alfalfa mixture at late harvest. Agron. J. 96: 951-955.

Bilbao, M., J.J. Martinez, and A. Delgado. 2004. Evaluation of soil nitrate as a predictor of nitrogen requierment for sugar beet grown in meditteranean climate. Agron. J. 96: 18-25.

Borreani, G., P.P. Roggeo, L. Sulas, and M.E. Valente. 2003. Quantifying morphological stage to predict the nutritive value in sulla
(Hedysarum coronarium L.). Agron. J. 95: 1608-1617.

Brink, G.E., M.D. Casler, and M.B. Hall. 2007. Canopy structure and NDF difference among temperate perennial grasses. J. Anim. Sci. 47: 2182-2189.

Chen, C.P. and E.M. Hutton. 1992. Growth and productivity of guinea grass for animal production. Proceeding XV Malaysian Society of Animal Production Annual Conference. Vision 2020 Towards More Efficient and Effective Animal Production Strategies. May 26-27 May 1992, Kuala Terengganu, Malaysia. Ed: H.K. Wong, H. Kassim, and M.A. Rajion.

Cherney, D.J.R., J.S. Jones, and A.N. Pell. 1992. Technical note: Forage in vitro dry matter digestibility as influenced by fiber source in the donor cow diet. J. Anim. Sci. 71: 13351338 .

Downing, T. and P. French. 2009. Improved understanding of fiber digestibility in ryegrasses. Journal of Extension 67(2): 252257.

Graybill, J.S., W.J. Cox, and D.J. Otis. 1991. Yield and quality of forage maize as influenced by hybrid, planting date and plant density. Agron. J. 83: 559-564.

Hartadi, H., S. Reksohadiprojo, dan A.D. Tillman. 1997. Tabel Komposisi Pakan untuk Indonesia. Cetakan kedua, Gadjah Mada University Press, Yogyakarta.

Holshouser, D.L. and J.P. Whittaker. 2002. Plant population and row spacing effects on early soybean production systems in the mid Atlantic USA. Agron. J. 94: 603-611.

Huntington, G.B. and J.C. Burns. 2008. The interaction of harvesting time of day of swithgrass hay and ruminal degradability of supplemental protein offered to beef steers. J. Anim. Sci. 86: 159-166.

Jian-Kang, Z. 2001. Plant salt tolerante. Science Direct. February 2001: 66-71.

Jung, H.G. and K.P. Vogel. 1986. Influence of lignin on digestibility of forage cell wall material. J. Anim. Sci. 62: 1703-1713.

Kefale, D. and S.L. Ranamukhaarachchi. 2006. Respon of maize varieties to drought stress at different phonological stages in Ethiopia. Wiley Inter Science 44(2): 61-66.

Lauer, J.G. and M. Rankin. 2004. Corn response to wthin row plant spacing variation. Agron. J. 96: 1464-1468.

Muir, J.P., W.R. Ocumpaugh, and J.C. Read. 2003. Spring forage yield and nutritive value of Texas black medic accessions. Agron. J. 95: 908-912. 
Orndorff. Z.W., W.L. Daniels, and D.S. Fanning. 2008. Reclamation of acid sulfate soils using lime stabilized biosolids. J. Environ. Qual. 37: 1447-1455.

Qian, Y.L., S.J. Wilhelm, and K.B. Marcum. 2001. Comparative responses of two kentucky blue grass cultivars to salinity stress. Crop Sci. 41: 1895-1900.

Reeves, J.B. 1985. Lignin composition and in vitro digestibility of feeds. J. Anim Sci. 60: 316322.

Scarbrough, D.A., W.K. Coblentz, J.B. Humphry, K.P. Coffey, T.J. Sauer, J.A. Jennings, T.C. Daniel, J.E. Turner, and D.W. Kelog. 2004. Estimating losses of dry matter from simulated rainfall on Bermuda grass and orchard grass forages using cell wall components as marker. Agron. J. 96: 16801687.
Steel, R.G.D. dan J.H. Torrie. 1990. Principles and Procedures of Statistic. Edisi Bahasa Indonesia. Gramedia Pustaka Utama, Jakarta (Diterjemahkan oleh Bambang Sumantri).

Stranger, T.F. and J.G. Lauer. 2006. Optimum plant population on $\mathrm{Bt}$ and non $\mathrm{Bt}$ corn in Wisconsin. Agron. J. 98: 914-923.

Utomo, R., D. Soetrisno, dan H. Hartadi. 1983. Pengaruh Naungan terhadap Hasil, Nilai Gizi dan Nilai Cerna Beberapa Jenis Rumput. Laporan penelitian. Fakultas Peternakan UGM, Yogyakarta.

Van Soest, P.J. 1994. Nutrition Ecology of the Ruminant. $2^{\text {nd }}$ ed. Comstock Publishing Associates A Division of Cornell University Press, London.

Widdicombe, W.D. and K.D. Thelen. 2002. Row width and plant density effect on corn forage hybrid. Agron. J. 94: 326-330. 